\title{
EKSPLORASI ASPEK SOSIO-EKOLOGI UNTUK MENDUKUNG PEMBANGUNAN KAWASAN WISATA BERWAWASAN LINGKUNGAN DI KAWASAN EKOSISTEM ESENSIAL PULAU BELIBIS, SOLOK
}

\author{
Muhammad Nazri Janra"), Henny Herwina, Mairawita dan Jabang Nurdin \\ Jurusan Biologi Fakultas Matematika dan Ilmu Pengetahuan Alam Universitas Andalas. \\ ") Email: mnjanra@sci.unand.ac.id
}

\begin{abstract}
ABSTRAK
Kawasan Ekosistem Esensial (KEE) Pulau Belibis yang terletak di Kabupaten Solok, Sumatera Barat dikenal dahulunya sebagai habitat untuk burung belibis (Dendrocygna javanica) dalam populasi yang signifikan. Seiring dengan pembangunan keparawisataan di kawasan ini melalui pembukaan kawasan, penambahan fasilitas rekreasi dan pembangunan hunian baru di sekitarnya, membuat aspek ekologis kawasan ini kurang terperhatikan. Wacana untuk mengembalikan ciri khas wilayah yang dihuni, terutama oleh, burung belibis telah dicanangkan oleh Pemerintah Kabupaten Solok baru-baru ini. Mengingat kawasan ini telah sangat dipengaruhi oleh keberadaan manusia, maka aspek sosio-ekologinya sangat penting untuk diketahui dalam menunjang usaha pengembangan daerah wisata yang berwawasan lingkungan. Untuk itulah sebuah survey sosio-ekologi dilakukan untuk mengetahui persepsi dan pengetahuan masyarakat terhadap kawasan dan biodiversitas Pulau Belibis dalam hubungannya dengan kegiatan parawisata di dalamnya. Delapan belas orang responden yang terdiri dari pengunjung dan warga sekitar disurvey dengan menggunakan kuisioner berisi pertanyaan seputar aspek sosioekologi, untuk kemudian dianalisa secara deskriptif. Analisis terhadap hasil survey menunjukkan bahwa sebagian besar pengunjung puas dengan kondisi terkini objek wisata, tetapi menyatakan bahwa sistem pengelolaan kawasan masih perlu ditingkatkan. Terdapat indikasi partisipatif dari para responden untuk turut menjaga kondisi lingkungan di Pulau Belibis. Sebagian besar responden mempunyai pengetahuan mengenai hewan atau tumbuhan alami yang ada di sana, bahkan semenjak sebelum pengembangan kawasan Pulau Belibis; tetapi keberadaan biodiversitas alami tersebut bukan menjadi alasan responden untuk berkunjung ke kawasan. Temuan ini mengisyaratkan perlunya usaha lebih lanjut untuk mengangkat kekayaan hayati di Pulau Belibis sebagai bagian dari ekowisata, misalnya dengan mengisolasi sebagian kawasan dari pengaruh manusia sehingga biodiversitas alami dapat kembali berkembang, membuat kandang terbatas untuk memelihara belibis yang diintroduksi kembali ke kawasan, atau dengan cara lainnya.
\end{abstract}

Kata Kunci: biodiversitas, burung belibis, kuisioner, responden, wisata lingkungan

\section{Exploration on Socio-Ecology Aspects to Support The Development of Environmental-Friendly Tourism Spot in Essential Ecosystem Area of Belibis Island, Solok}

\begin{abstract}
Essential Ecosystem Area (EEA) Belibis Island is located in Solok Regency, West Sumatra Province which renown as the habitat for significant population of Whistling Ducks Dendrocygna javanica (vernacular name: Belibis). In line with the development of tourism sector in this area, through site clearing, the building of recreational facilities and human establishment, seem to have neglected the ecological aspect during the process. The idea to recover the typical characteristic of this area as habitat for the whistling ducks has been recently stated by the Municipal Authority of Solok City. Recalling that this area has been severely impacted by human, hence comprehending its socio-ecological aspects becomes essential to support the development of an environmental-friendly ecotourism activity herein. Therefore, a socio-ecological survey was then conducted to understand the perception and knowledge of local community toward the biodiversity in Belibis Island, especially in its relation to the tourism activity. Eighteen respondents, consisted of visitors and local people, were inquired using socio-ecological
\end{abstract}


questionnaire, which later descriptively analyzed. The result showed that most of the respondents satisfied with the current condition of Belibis Island, with emphasis for further improvement on the management system. There was indication of people willingness to participate in maintaining the environmental condition. Lot of respondents possess knowledge regarding wild plants and animals in Belibis Island, even before the establishment of tourism site in that area; however, the existence of these wildlife not what attracted them to come. These findings indicate the needs to further improve natural biodiversity in Belibis Island as focal point for ecotourism destination. It can be achieved, presumably, through isolating some parts of the area from human interference to help the thriving of natural wildlife, constructing nature-basesd aviary to introduce the whistling ducks or other wild birds, as well as deploying any other way.

Keywords: biodiversity, ecotourism, questionnaire, respondent, whistling ducks

\section{PENDAHULUAN}

Pariwisata beserta semua kegiatan pendukungnya seperti travel, perhotelan, kuliner dan sebagainya merupakan salah satu bentuk industri yang berkembang paling cepat belakangan ini. World Tourist Organization atau Organisasi Pariwisata Dunia melaporkan bahwa penerimaan devisa dari sektor pariwisata internasional terus tumbuh sekitar 9\% pada periode 1988-1997 dan diprediksi mencapai 1 bilyun dollar Amerika pada dasawarsa berikutnya (Wood 2002). Di antara sektor pariwisata yang cukup cepat perkembangannya adalah wisata lingkungan atau yang dikenal dengan istilah ekoturisme, dimana para pelancong melakukan kunjungan ke suatu tempat dengan tujuan untuk menikmati keindahan alamnya tanpa menimbulkan kerusakan terhadap kondisi lingkungan yang ada (The International Ecotourism Society 1991). Ekoturisme juga memberikan jaminan keberlangsungan pemanfaatan lingkungan dengan dampak minimal sembari melestarikan sumber daya lingkungan dan nilai sosiobudaya lokal (Butarbutar \& Soemarno 2013). Sehingga wajar, pengembangan sektor pariwisata berbasis lingkungan menjadi salah satu prioritas dari pemerintah baik di tingkat pusat maupun daerah.
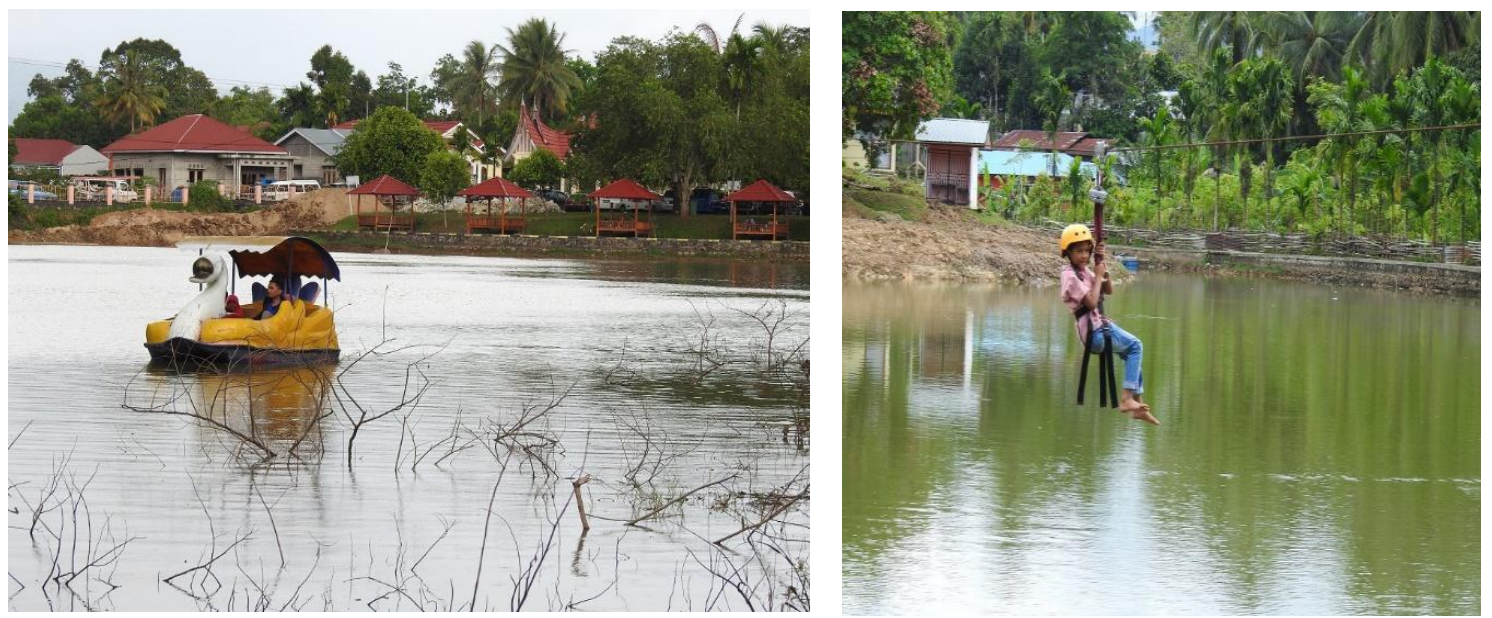

Gambar 1. Dua Wahana Wisata Yang Ada Di Pulau Belibis: Perahu Bebek Dan Flying Fox 
Pulau Belibis terletak di dalam wilayah administratif Kota Solok, berjarak sekitar 2 kilometer dari Pasar Kota Solok dan dekat dengan gelanggang pacuan kuda Ampang Kualo (Pemda Kota Solok, 2018). Kawasan ini telah dibangun sedemikian rupa untuk menjadi tempat wisata dengan berbagai fasilitas seperti sepeda air, flying fox, arena pemancingan dan bola air. Berdekatan dengan kawasan ini, terdapat dengan Taman Pramuka yang dilengkapi dengan sarana outbond dan sering menjadi lokasi gathering untuk berbagai acara. Kedua fasilitas tersebut, semenjak pembukaan kembalinya pada pertengahan tahun 2018 pernah dikunjungi sampai lebih dari 2.000 orang wisatawan dalam satu hari (Harian Singgalang 2018). Semakin banyaknya pengaruh aktifitas manusia (antropogenik) pada kawasan ini, mengakibatkan tidak dapat lagi ditemukannya keberadaan burung Belibis (Dendrocygna javanica; Anatidae) secara yang menjadi sumber awal penamaan daerah tersebut. Selain itu, pembukaan kawasan dan penambahan fasilitas kegiatan manusia mempunyai pengaruh yang negatif terhadap keberadaan beragam hidupan hayati liar yang ada di sekitar wilayah tersebut.

Pemerintahan Daerah Kota Solok mempunyai keinginan untuk mengembalikan keberadaan burung Belibis di kawasan ini, yang sekaligus dapat dijadikan ikon untuk pariwisata berbasis lingkungan. Akan tetapi, mengingat pembangunan kawasan yang telah dilakukan sudah berjalan sedemikian rupa, selain dengan makin intensifnya kegiatan manusia di dalamnya, tentu akan menimbulkan tantangan tersendiri dalam mewujudkan keinginan tersebut. Sebelum memulai kegiatan yang bertujuan untuk memulihkan kondisi lingkungan kawasan, satu hal yang harus terlebih dahulu dipahami adalah bagaimana persepsi manusia terhadap lingkungannya di dalam kawasan yang telah diberi predikat Kawasan Ekosistem Esensial (KEE) tersebut. Karena pada akhirnya, unsur manusialah yang akan menentukan keberhasilan kegiatan yang dimaksudkan tersebut. Untuk itulah dilakukan survey bertema sosioekologi dilakukan di kawasan KEE Pulau Belibis dengan tujuan untuk menghimpun informasi awal yang menjadi dasar untuk pengembangan lebih lanjut kawasan menjadi tujuan wisata berbasis lingkungan.

\section{METODE}

Kegiatan ini berupa pengambilan data sosioekologi ini telah dilakukan terhadap pengunjung dan masyarakat di sekitar KEE Pulau Belibis Solok pada tanggal 9 September 2018. Metode yang digunakan adalah survey dengan menggunakan kuisioner yang telah dirancang sedemikian rupa untuk mendapatkan data persepsi sosial terhadap keberadaan KEE Pulau Belibis, serta data pengetahuan lingkungan (Lampiran 1). Kuisioner yang diberikan terdiri dari dua bagian utama, yaitu aspek sosial untuk mendapatkan persepsi responden terhadap keberadaan KEE Pulau Belibis serta kegiatan pariwisata yang ada di dalamnya, serta aspek ekologis dimana responden diminta untuk menyampaikan pengetahuan mereka terhadap lingkungan dan kekayaan hayati yang ada di dalam kawasan tersebut. Pertanyaan dalam kuisioner dibuat dalam bentuk tertutup (dengan alternatif jawab disediakan) dan tertutup, sehingga dapat digunakan sekaligus sebagai panduan dalam wawancara lepas (Janra dan Fandri, 2018). 

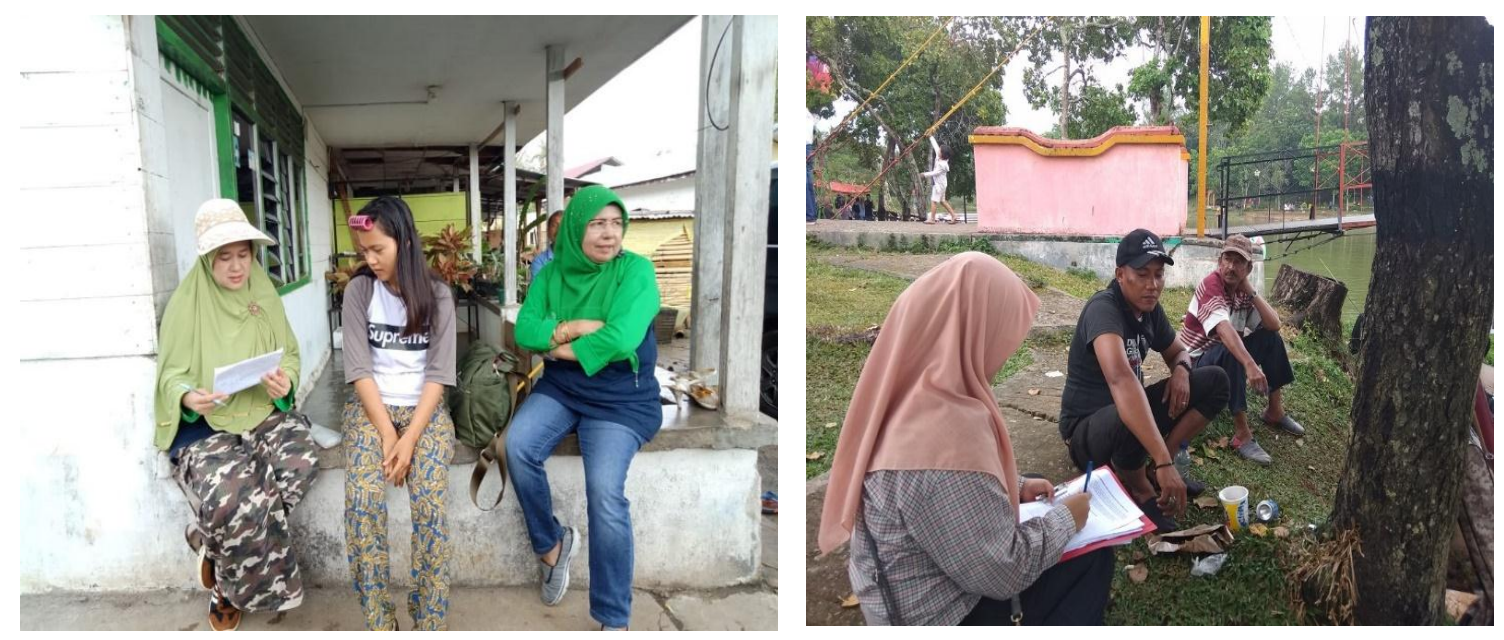

Gambar 2. Kegiatan Survey dan Wawancara dengan Responden Berupa Pengunjung dan Masyarakat Sekitar KEE Pulau Belibis

Pelaksanaan survey untuk pengambilan data dilakukan melalui wawancara dengan menggunakan kuisioner kepada para pengunjung yang ada pada saat itu di kawasan KEE Pulau Belibis. Selain itu, survey juga dilakukan pada masyarakat sekitar KEE Pulau Belibis, terutama yang telah tinggal di kawasan selama lima tahun atau lebih, sehingga didapatkan ragam persepsi terhadap kawasan. Dalam setiap kali sesi wawancara, pencacah meminta kesediaan calon responden serta memberikan jaminan terhadap data dan informasi yang mereka berikan. Pemberian jaminan di awal wawancara ini secara psikologis membuat responden merasa nyaman dalam memberikan informasi yang dicari melalui survey. Pencacah juga mendampingi responden dalam menjawab pertanyaan yang diberikan, melalui penyampaian dengan bahasa yang mudah dimengerti, sehingga dapat dipastikan bahwa jawaban yang diberikan berdasarkan pemahaman mereka terhadap esensi pertanyaan yang diberikan.

Data yang didapatkan melalui survey dengan kuisioner kemudian ditabulasikan sesuai dengan kategori masing-masing. Untuk pertanyaan kuisioner yang berupa pilihan berganda, dilihat kecenderungan responden dalam memilih suatu opsi jawaban, sedangkan untuk pertanyaan essay, jawaban responden dikategorikan dan dikelompokkan berdasarkan kedekatan makna jawaban masing-masing responden. Total jawaban kemudian dianalisa secara deskriptif untuk menentukan kecenderungan jawaban responden terhadap suatu item pertanyaan. Rekomendasi kepada Pemerintah Daerah Solok dalam pembangunan kawasan wisata berwawasan lingkungan disintesis dari analisa terhadap jawaban yang diberikan oleh responden dan dihubungkan dengan pengamatan secara langsung di lapangan terhadap aspek-aspek sosioekologis yang ditanya di dalam kuisioner.

\section{HASIL DAN PEMBAHASAN}

\section{Responden}

Dari survey yang telah dilakukan, berhasil diwawancarai 18 orang responden yang terdiri dari 8 laki-laki dan 10 orang perempuan. Sebanyak 7 orang (terdiri dari 2 lakilaki dan 5 perempuan) merupakan warga yang bertempat tinggal di sekitar KEE Pulau 
Belibis, sedangkan sisanya merupakan pengunjung. Tiga orang responden bekerja sebagai ibu rumah tangga, 7 orang lagi bekerja dalam berbagai sektor swasta sedangkan sisanya tidak bersedia memberikan informasi mengenai pekerjaan mereka. Dari ketujuh orang warga sekitar yang menjadi responden di dalam survey ini, tidak ada bekerja pada sector yang berhubungan langsung dengan keberadaan kawasan wisata KEE Pulau Belibis.

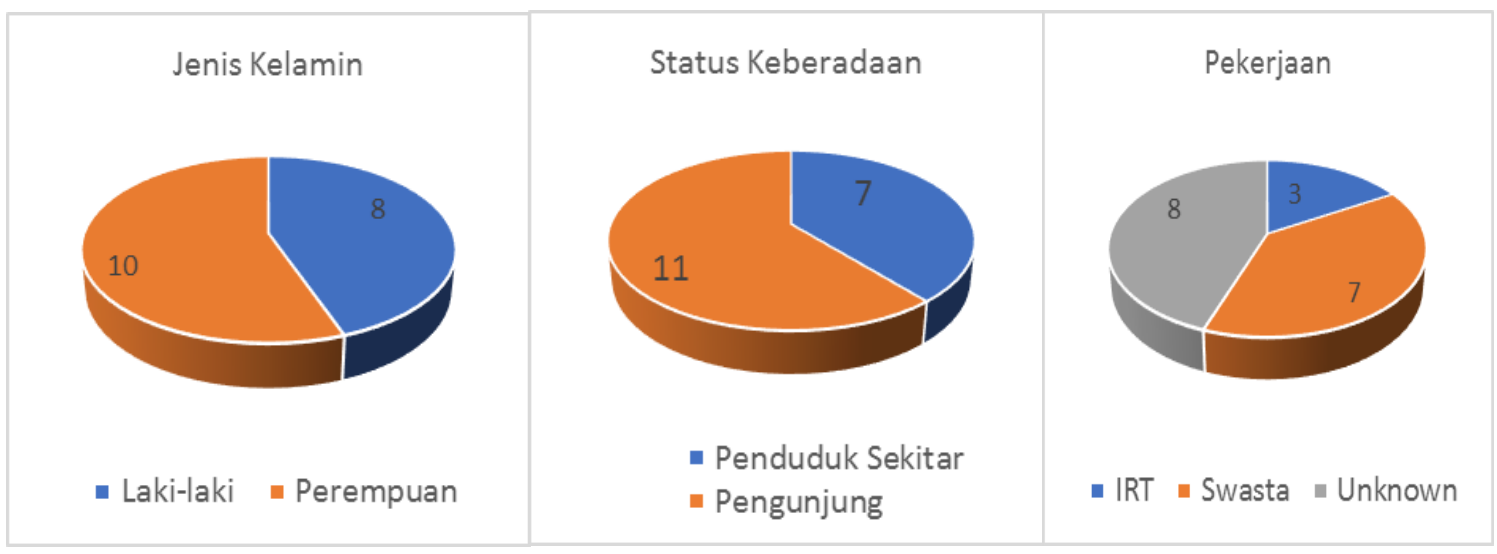

Gambar 3. Data Demografi Singkat Dari Responden Yang Telah Diwawancarai Dalam Survey

Dalam pengambilan data yang bersinggungan dengan aspek kemasyarakatan, beberapa hal dapat menjadi penentu kualitas data yang akan diperoleh seperti kedekatan responden dengan hal yang disurvey serta interaksi mereka dengan objek yang disurvey tersebut (Blankenship et al. 2000; Neuman 2014). Dalam hal survey sosioekologis terhadap KEE Pulau Belibis ini, mendapatkan responden yang merupakan penduduk sekitar di samping mewawancarai pengunjung kawasan akan memberikan sudut pandang yang berbeda, sehingga terdapat beragam dimensi yang bisa dilihat dari aspek yang dikaji. Diasumsikan, jika penduduk sekitar KEE Pulau Belibis merasakan manfaat dari keberadaan kegiatan pariwisata yang berlangsung (terutama dari sisi ekonomi), maka mereka akan menghargai keberadaan kawasan. Sebaliknya, jika kegiatan yang dilakukan di dalam kawasan tidak memberikan dampak apapun kepada warga sekitar, masyarakat cenderung akan bersikap pasif dan statis.

\section{Aspek Sosial Kawasan}

Terdapat enam butir pertanyaan yang diberikan di dalam aspek sosial ini, yang umumnya bertujuan untuk mengetahui persepsi pengunjung dan masyarakat sekitar terhadap pembangunan objek wisata di KEE Pulau Belibis serta pengelolaannya. Item pertanyaan nomor 3 dan 6 pada kategori ini dibuat dalam bentuk pertanyaan terbuka untuk memberi keleluasaan responden menilai kondisi keseluruhan KEE Pulau Belibis serta harapan peningkatan di masa yang akan datang. Pertanyaan pertama mengenai pengelolaan kawasan KEE Pulau Belibis, dimana responden menjawabnya dengan sangat baik dan baik (masing-masing 7 orang atau 38.89\%). Sebanyak 4 orang responden $(22.22 \%)$ mengatakan bahwa kawasan tersebut masih belum dikelola dengan baik terutama dengan alasan masih belum selesainya pembangunan beberapa fasilitas yang ada di dalam kawasan (Gambar 4A). Selaras dengan hal itu, pada pertanyaan 
kedua mengenai kebersihan kawasan (Gambar 4B), mayoritas responden (12 orang, $66.67 \%$ ) menjawab sangat bersih, diikuti dengan 5 orang $(27.78 \%)$ menjawab bersih serta 1 orang $(5.56 \%)$ menjawab tidak tahu. Tidak ada responden pada pertanyaan ini yang menganggap bahwa KEE Pulau Belibis berada dalam keadaan kotor. Semua responden $(100 \%)$ juga berpendapat sama bahwa Pulau Belibis yang sekarang jauh lebih baik kondisinya daripada waktu sebelum dibangun fasilitas wisatanya (Gambar 4C).
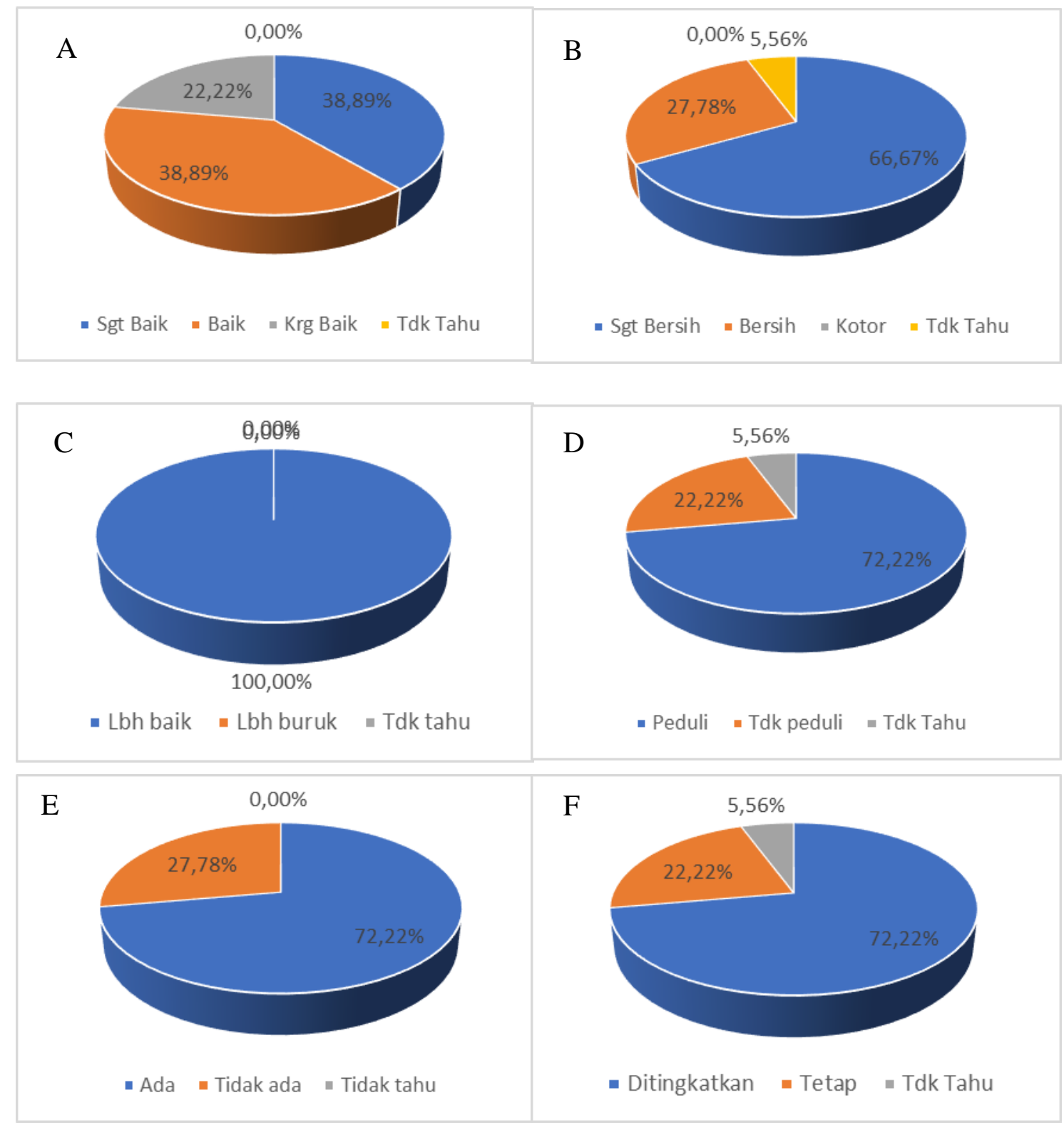

Gambar 4. Tabulasi Jawaban Responden Pada Enam Poin Pertanyaan Sosial

Dua pertanyaan berikutnya di dalam kategori ini membahas tentang ketertiban dan kepedulian terhadap lingkungan. Sebanyak 13 orang responden $(72.22 \%)$ menyatakan bahwa pengunjung dan pengguna KEE Pulau Belibis mempunyai kepedulian terhadap kebersihan, ketertiban dan keindahan (K3) saat menggunakan fasilitas yang ada 
(Gambar 4D). Jumlah responden yang sama menyatakan bahwa terdapat (atau seharusnya terdapat) kontrol sosial berupa teguran atau peringatan jika ada tindakan yang menyebabkan gangguan terhadap K3 terjadi di dalam KEE Pulau Belibis (Gambar 4E). Terdapat 4-5 orang responden (22.22\%-27.78\%) yang menyatakan tidak peduli dengan masalah K3 di KEE Pulau Belibis seperti yang ditanyakan pada pertanyaan ketiga, atau menyatakan tidak tahu dengan adanya sanksi sosial terhadap gangguan pada K3 kawasan. Hanya pada pertanyaan keempat ini terdapat satu orang respondens $(5.56 \%)$ yang menyatakan tidak tahu sama sekali mengenai masalah kebersihan kawasan. Sebanyak 13 orang responden (72.22\%) mengharapkan terus adaya peningkatan fasilitas di kawasan ini, misalnya seperti penambahan tempat sampah, penambahan jalur jogging bahkan diadakannya penangkaran bagi burung belibis (item pertanyaan 6, Gambar 4F). Pada pertanyaan terakhir di kategori ini, terdapat 4 orang responden $(22.22 \%)$ yang menjawab tidak perlu adanya peningkatan pada fasilitas serta 1 orang $(5.56 \%)$ yang menjawab tidak tahu.

Terdapat kecenderungan yang cukup baik mengenai persepsi sosial masyarakat terhadap keberadaan KEE Pulau Belibis dengan tingkat kepuasan terhadap fasilitas dan kondisi kawasan yang cukup tinggi. Hal ini agak sedikit berbeda dengan temuan Yanda (2017) yang menyatakan bahwa walaupun di KEE Pulau Belibis terdapat fasilitas dan infrastruktur penunjang kepariwisataan, tetapi masih dalam kondisi yang belum memadai yang berimbas kepada optimalitas pelayanan kepada pengunjung dan pengguna kawasan. Memang sebagai kawasan yang bertujuan untuk memberikan jasa rekreasi kepada banyak orang sudah selayaknya kawasan ini selalu berada dalam kondisi yang prima. Walaupun demikian, terdapat rasa tanggungjawab untuk memelihara fasilitas dan lingkungan di kawasan ini, seperti yang diindikasikan oleh sebagian besar pengunjung dan masyarakat sekitar yang dapat dipergunakan sebagai asset dalam menjaga kondisi K3 kawasan.

\section{Aspek Ekologis Kawasan}

Aspek ekologi dari KEE Pulau Belibis menjadi inti utama dari survey ini, dimana terdapat 10 butir pertanyaan. Lima pertanyaan dalam format pertanyaan tertutup atau semi tertutup, sedangkan sisanya dalam bentuk pertanyaan terbuka. Tiga hal pokok yang dituju di dalam bagian survey ini adalah; 1) frekuensi kunjungan responden ke KEE Pulau Belibis, 2) pengetahuan responden tentang kondisi lingkungan dan keanekaragaman hayati yang ada atau pernah ada sebelumnya, serta 3) bentuk pemanfaatan yang dilakukan di kawasan tersebut. Terdapat hubungan yang erat antara poin 1 dan 2 pada aspek ekologis survey ini, dimana responden yang sering melakukan kunjungan atau memanfaatkan kawasan KEE Pulau Belibis akan mempunyai lebih banyak informasi tentang lingkungan dan kekayaan hayati yang ada di sana; informasi yang diberikan oleh responden seperti ini mempunyai tingkat kepercayaan yang lebih tinggi dibandingkan dengan responden yang baru pertama kali berkunjung ke kawasan ini.

Dari delapan belas responden yang diwawancarai, mayoritas 16 orang (88.89\%) telah berkunjung lebih dari lima kali dan dalam rentang waktu lebih dari 2 tahun yang lalu, serta 2 orang (11.11\%) telah berkunjung antara 2-5 kali ke KEE Pulau Belibis (Gambar 5A, 5B). Tidak ada dari responden yang merupakan pengunjung baru di kawasan ini. Hal ini sangat berpengaruh pada data yang diberikan, karena informasi 
yang mereka berikan berdasarkan pada persepsi yang telah terbentuk dari interaksi berulang kali dengan kawasan yang menjadi objek kajian survey ini. Rata-rata dari pengunjung berulang ini menghabiskan waktu lebih dari 2 jam ketika berada di dalam kawasan dan hanya dua responden yang mengaku menghabiskan waktu kurang dari 2 jam untuk menikmati fasilitas yang ada (Gambar 5C). Sebanyak 13 orang responden mengungkapkan bahwa mereka merasakan adanya perubahan kawasan semenjak kunjungan pertama mereka dengan saat sekarang ini, terutama pada aspek kebersihan, kondisi lingkungan yang lebih alami dan tingkat aktifitas manusia yang lebih jarang (Gambar 5D). Sebanyak 4 orang (22.22\%) responden menyatakan kalau kawasan tersebut dahulunya tidak sebersih yang sekarang; hanya satu responden menjawab tidak tahu untuk poin pertanyaan ini.

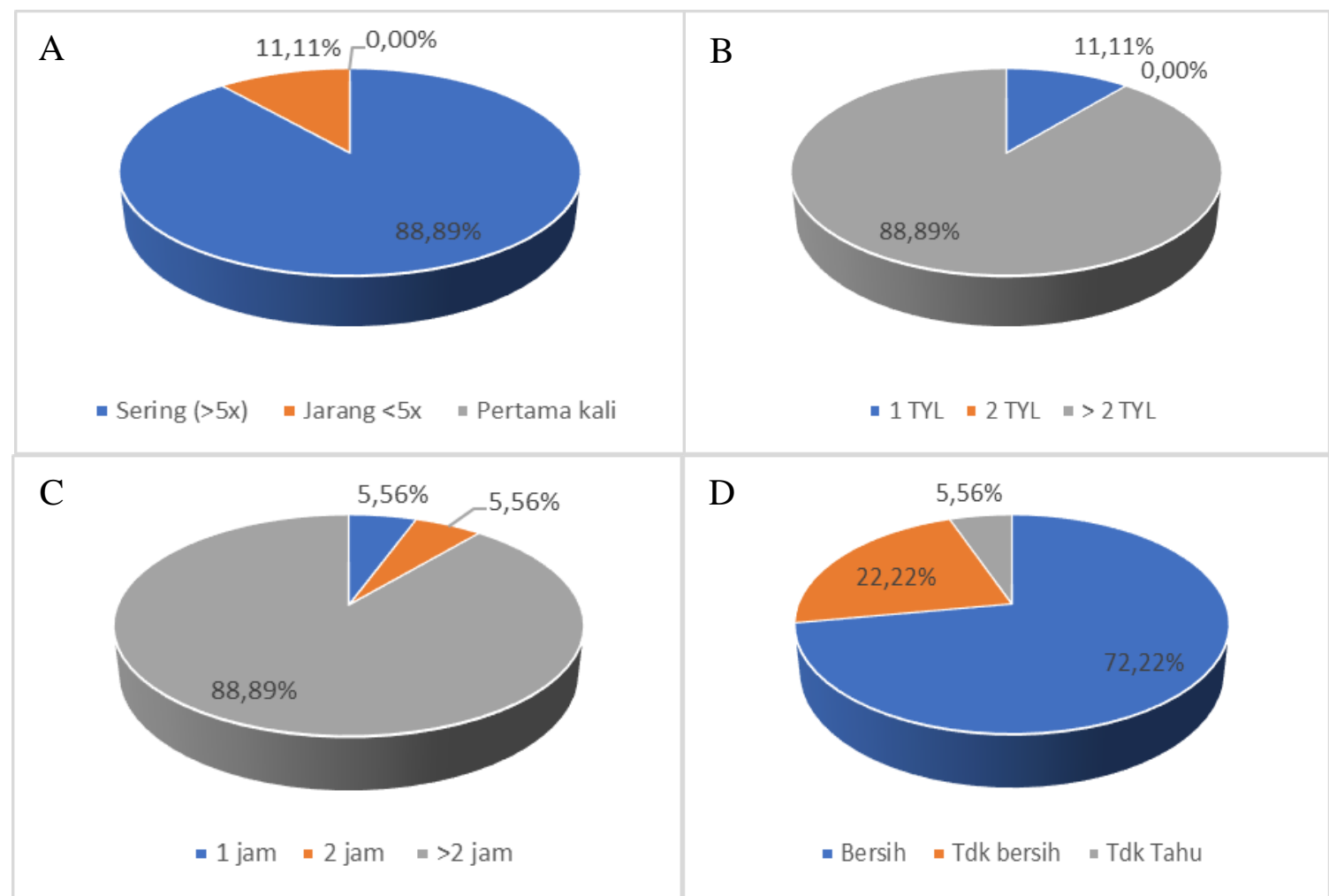

Gambar 5. Tabulasi jawaban responden terhadap pertanyaan mengenai frekuensi kunjungan, kunjungan pertama dan lama kunjungan yang dilakukan responden di KEE Pulau Belibis

Sebanyak 14 orang $(77.78 \%)$ responden mengetahui apa yang dimaksud dengan burung belibis dan bahkan pernah melihat secara langsung di lapangan (Gambar 6A, 6B). Beberapa responden dapat dengan teliti menjelaskan bahwa belibis merupakan sejenis burung air yang mirip dengan itik. Menurut keterangan yang diberikan oleh 12 orang $(66.67 \%)$ responden, burung belibis ini diketahui paling awal telah ada pada tahun 1985 di KEE Pulau Belibis, sedangkan paling terakhir terlihat pada tahun 2015 (Gambar 6C). Burung ini sendiri pernah terhitung antara 15-25 ekor pada tahun 2006 (Janra, pers. obs), tetapi setelah itu tidak ada lagi survey ilmiah yang dilakukan terhadap keberadaan burung ini di KEE Pulau Belibis. Selain dari kawasan yang disurvey ini, responden mengaku juga pernah melihat burung belibis di beberapa lokasi lain. Informasi dari salah seorang responden yang mengatakan pernah melihat burung belibis 
dalam waktu yang tidak terlalu lama di kawasan tersebut perlu untuk dikonfirmasi kebenarannya. Kondisi lingkungan di KEE Pulau Belibis dengan tingkat aktifitas manusia yang tinggi sebenarnya sangat tidak kondusif untuk keberadaan jenis burung yang sangat pemalu dan rentan terhadap gangguan yang ditimbulkan oleh manusia ini (MacKinnon dkk. 2000).

Poin pertanyaan selanjutnya adalah untuk mengetahui apa saja hewan liar selain burung belibis yang pernah teramati oleh responden (Gambar 6D). Pertanyaan ini dijawab pernah oleh 7 orang responden, dimana sejumlah hewan liar seperti biawak (Varanus salvator), tupai garis (Calosciurus notatus), bangau (Bubulcus ibis) serta beberapa jenis burung liar lainnya. Keberadaan hewan-hewan ini beberapa di antaranya juga teramati saat survey sosioekologi ini dilakukan.
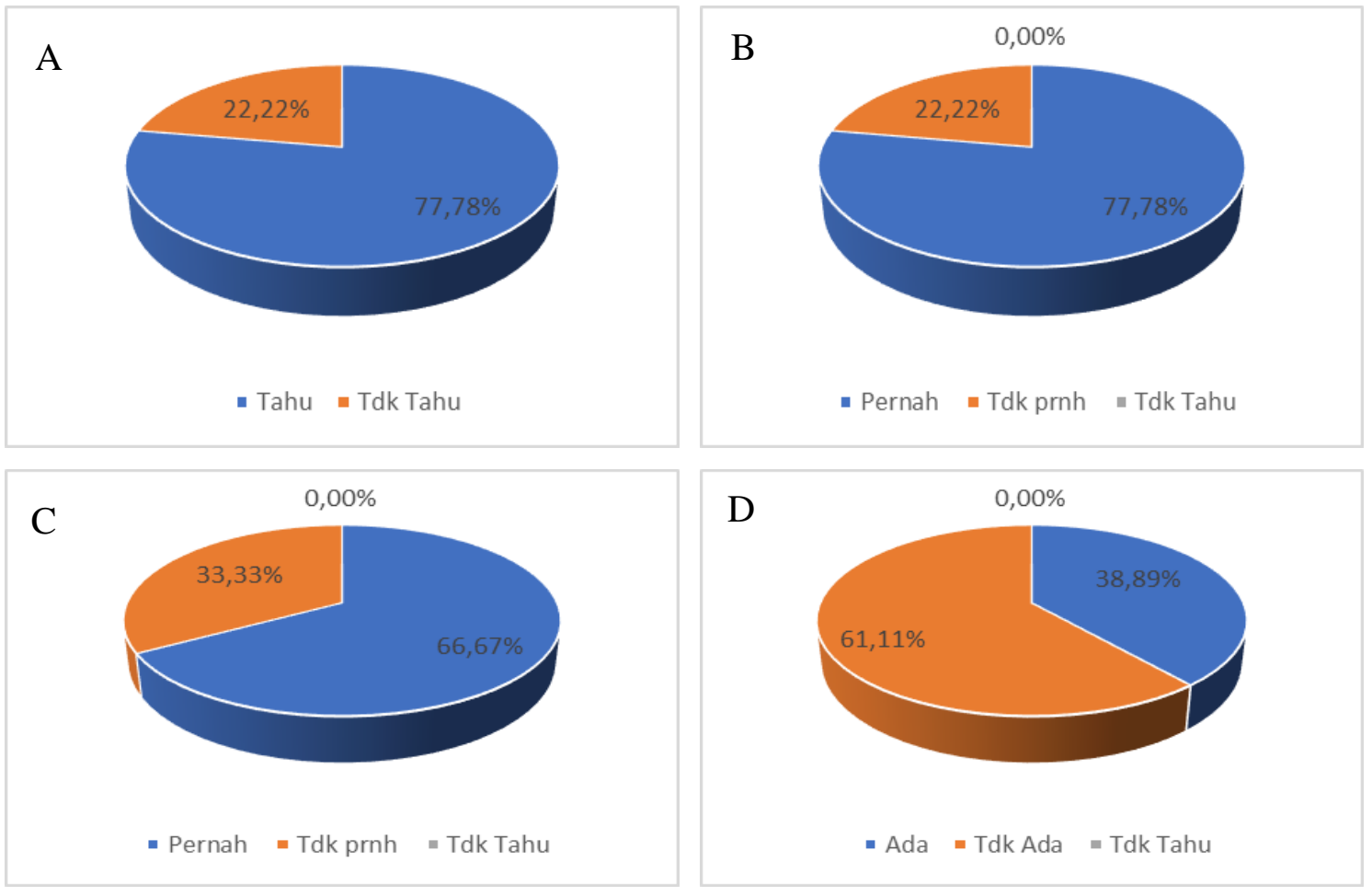

Gambar 6. Tabulasi Jawaban Responden Terhadap Pertanyaan Seputar Pengetahuan Mereka Tentang Burung Belibis Dan Hidupan Liar Lain Di Kee Pulau Belibis

Hal terakhir yang ditanyakan di dalam survey ini adalah bagaimana bentuk pemanfaatan terhadap kawasan yang dilakukan oleh responden. Kebanyakan hal yang dilakukan oleh responden (55.56\%) berkaitan dengan beragam event atau acara yang diadakan pada KEE Pulau Belibis atau pada Taman Pramuka yang ada di sebelahnya (Gambar 7A). Sedangkan 5 orang responden (27.78\%) mengaku khusus datang untuk menikmati keindahan alam, dimana 4 orang lainnya (22.22\%) menggunakan KEE Pulau Belibis sebagai tempat untuk berkumpul menghabiskan waktu bersama teman atau anggota keluarga atau juga berpiknik. Hanya satu orang responden yang menyatakan bahwa kedatangannya ke kawasan ini untuk menggunakan berbagai wahana air yang ada. Bagi kebanyakan responden (12 orang responden, 66.67\%), aspek yang menyebabkan mereka tertarik untuk datang berwisata ke KEE Pulau Belibis adalah 
karena keasriannya (Gambar 7B). Kemudian diikuti oleh 4 orang responden $(22.22 \%)$ yang datang karena beragam acara yang diadakan di kawasan ini, serta dua orang $(11.11 \%)$ yang datang karena ingin mendapatkan suasana kawasan yang tenang dan jauh dari hiruk pikuk kota. Pada point pertanyaan terakhir ini tidak ada responden yang menyatakan tertarik datang karena ragam tumbuhan atau hewan liar yang hidup di sana.
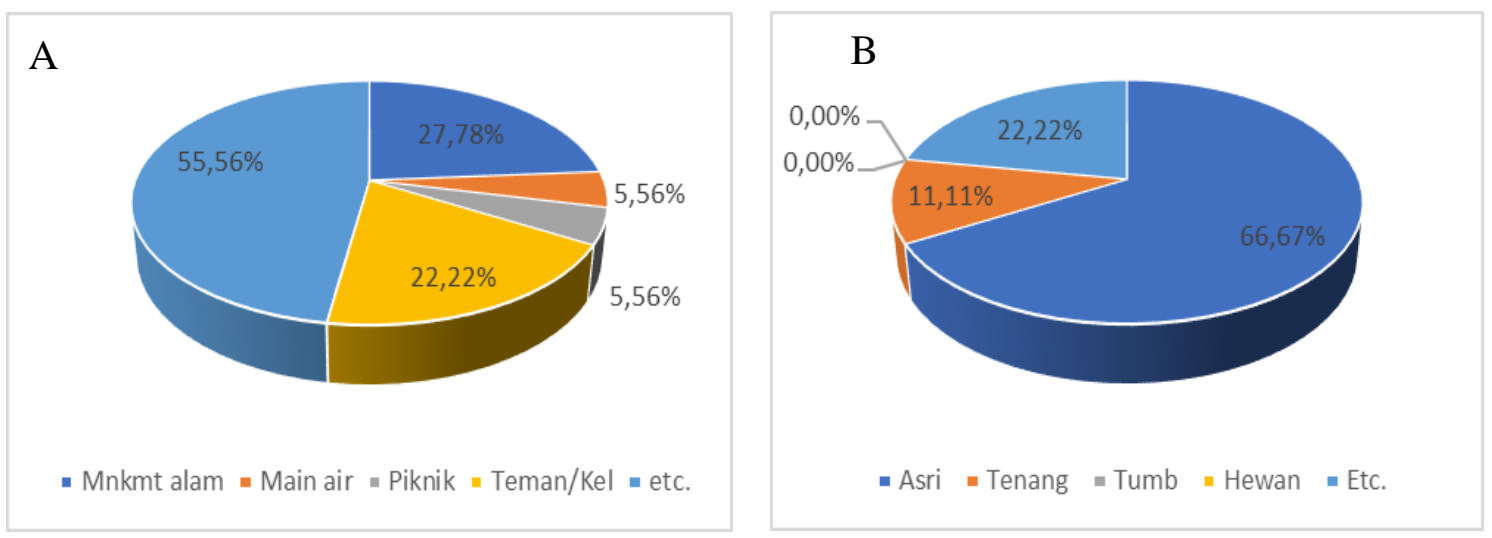

Gambar 7. Tabulasi Jawaban Responden Terhadap Pertanyaan Mengenai Aspek Pemanfaatan Kawasan.

Responden pada survey ini, yang merupakan cuplikan dari seluruh populasi masyarakat yag menjadi pengunjung atau pengguna KEE Pulau Belibis, secara umum menunjukkan pengetahuan tentang aspek lingkungan, terutama yang spesifik dengan ciri khas kawasan ini. Terlebih lagi, sebagian besar dari mereka mempunyai kesadaran dan apresiasi terhadap lingkungan dan fasilitas yang telah ada, sehingga bisa dianggap menjadi salah satu modal utama dalam menggerakkan kegiatan wisata berwawasan lingkungan. Sesuai dengan kondisi yang tergambar di dalam jawaban yang diberikan oleh, paling tidak kegiatan ekowisata pasif (dimana pengunjung datang menikmati kawasan tanpa melakukan kegiatan yang merusak lingkungan) dapat dilakukan (Wood 2002). Sedangkan ekowisata aktif yang mendorong pengunjung atau pelancong yang datang untuk ikut terlibat secara nyata di dalam kegiatan pelestarian alam yang ada di dalam kawasan, walaupun membutuhkan usaha untuk menuju ke arah tersebut, bukan tidak mungkin untuk juga diwujudkan pada KEE Pulau Belibis ini.

\section{Rekomendasi}

Terdapat beberapa hal penting yang dapat direkomendasikan dari hasil survey ini terhadap rencana untuk meningkatkan aspek ekologis dari KEE Pulau Belibis. Hal-hal tersebut antara lain adalah untuk terus melakukan sosialisasi mengenai nilai penting kekayaan hayati berikut lingkungannya di kawasan tersebut. Dapat dilakukan dalam bentuk penyuluhan secara berkala tentang nilai ekologis kawasan, peran penting tumbuhan dan hewan liar yang ada di kawasan tersebut atau dengan cara lainnya. Tujuan utama sosialisasi ini adalah untuk terus menjaga dan menumbuhkan persepsi dan perilaku penghargaan terhadap lingkungan dari setiap pengunjung dan pengguna kawasan. Hal berikutnya yang dapat disarankan kepada pemerintah daerah selaku pengelola kawasan adalah dengan membuat zonasi yang jelas di dalam KEE Pulau Belibis, dimana zona yang paling penting untuk dapat memancing kembali kehadiran burung belibis dan berbagai satwa liar lainnya adalah zona akses terbatas berikut dengan 
penyangganya. Di dalam zona ini, sebisa mungkin dibatasi adanya kegiatan manusia atau bisa diatur dalam bentuk kunjungan khusus ekowisata. Zonasi terbatas ini dapat dibiarkan secara alami atau dengan bantuan manusia, tetapi pada intinya adalah mengembalikan kondisi lingkungan sebagai habitat yang sesuai untuk burung belibis. Pembentukan zonasi untuk habitat burung belibis ini akan memakan waktu cukup lama, tetapi sangat berharga untuk dilakukan karena dapat menciptakan habitat yang stabil dan memadai bagi burung belibis. Jika hal ini terlalu lama, maka rekomendasi berikutnya yang mungkin untuk dilakukan adalah dengan menciptakan aviary atau kandang semi alami untuk memelihara dan membiakkan bukan saja burung belibis, tetapi beragam burung liar lainnya dalam habitat yang dibatasi. Kerjasama dengan pihak swasta dalam pembuatan aviary dapat dilakukan untuk mengatasi besarnya biaya yang dibutuhkan, selain kerjasama dengan perguruan tinggi untuk melakukan pemantauan dan penelitian terhadap satwa dan tumbuhan yang diasuh di dalamnya.

\section{KESIMPULAN DAN SARAN}

Dari kegiatan ini berupa survey sosioekologi ini dapat disimpulkan bahwa pengunjung dan pengguna KEE Pulau Belibis mempunyai persepsi sosial yang baik terhadap kegiatan wisata yang ada, termasuk kepada fasilitas dan lingkungan. Walaupun dari aspek ekologis dapat dikatakan pengunjung dan pengguna KEE Pulau Belibis mempunyai pengetahuan tentang lingkungan, kekayaan hayati serta nilai estetika terhadap lingkungan, tetapi penarik utama kedatangan mereka datang ke kawasan bukanlah karena adanya kekayaan hayati tertentu (terutama burung belibis) yang merupakan hal yang spesifik untuk kawasan ini. Diharapkan, melalui saran dan rekomendasi yang dihasilkan dari kegiatan survey ini dapat memberikan informasi awal yang dapat mendukung rencana pengembangan kembali satwa dan hidupan liar yang pernah ada serta pembentukan wisata berwawasan lingkungan di KEE Pulau Belibis ini.

\section{UCAPAN TERIMA KASIH}

Penulis mengucapkan terima kasih kepada Fithria Diniyati, Halimah Tus Sakdiah dan Leo Darmi terhadap bantuannya selama melakukan survey dan wawancara kepada responden. Terima kasih juga diberikan kepada Pemerintah Daerah Kota Solok yang telah memprakarsai dan memberikan bantuan selama pengambilan data di KEE Pulau Belibis melalui kontrak kerja nomor 556/011/SPK/DISPAR/2018.

\section{DAFTAR PUSTAKA}

Blankenship, K.M., S.J. Bray and M.H. Merson. 2000. Structural interventions in public health. AIDS 2000. 14(1): S11-S21.

Butarbutar, R and Soemarno. 2013. Environmental effects of ecotourism in Indonesia. Journal of Indonesian Tourism and Development Studies. 1(3): 97-107. 
Harian Singgalang. 2018. Pulau Belibis ramai dikunjungi wisatawan. Edisi 18 Juni 2018. Diakses dari https://hariansinggalang.co.id/pulau-belibis-ramai-dikunjungiwisatawan/

MacKinnon, J, K. Phillipps dan B. V. Balen. 1998. Burung-burung di Sumatera, Jawa, Bali dan Kalimantan. Seri Panduan Lapangan. Puslitbang Biologi-LIPI, Jakarta

Neuman, W.L. 2014. Social Research Methods: Qualitative And Quantitative Approaches. Seventh edition. Pearson Education Limited, Essex, England.

Pemerintah Daerah Kota Solok. 2017. Pulau Belibis. Diakses dari http://www.solokkota.go.id/index.php/component/k2/item/20-pulau-belibis pada tanggal 18 Desember 2018.

The International Ecotourism Society. 1991. What is ecotourim? Diakses pada http://www.ecotourism.org/what-is-ecotourism, tanggal 17 Desember 2018.

Yanda, R.P. 2017. Tinjauan kondisi fasilitas pada obyek wisata Pulau Belibis, Kota Solok, Sumatera Barat. Skripsi. Politeknik Negeri Padang, Padang.

Wood, M.E. 2002. Ecotourism: Principles, practices \& Policies for Sustainability. United Nations Environment Programme, Paris, France. 